\title{
Improving Quality of Sunn Hemp (Crotalaria Juncea L.) Foliage as Roughage Source for Ruminants by using Microorganisms
}

\author{
Chantira Wongnen ${ }^{1, *}$, Krittika Kabploy ${ }^{1}$, Pijug Summpunn ${ }^{1}$ and Suchat Suksathits ${ }^{2}$ \\ ${ }^{1}$ School of Agricultural Technology and Food Industry, Walailak University, \\ Nakhon Si Thammarat 80160, Thailand \\ ${ }^{2}$ Faculty of Technology and Community Development, Thaksin University, Phatthalung Campus, \\ Phatthalung 93110, Thailand
}

('Corresponding author's e-mail: chantira.wo@mail.wu.ac.th)

Received: 14 September 2020, Revised: 22 March 2021, Accepted: 14 April 2021

\begin{abstract}
This study aims to investigate the chemical composition, fermentation characteristics, and in vitro ruminal digestibility efficiency of Sunn hemp silage with Fermented juice of epiphytic lactic acid bacteria (FJLAB) and bacillus subtilis. The experiment was designed in a CRD. Five dietary treatments were fresh Sunn hemp (FS, the positive control), Sunn hemp silage (SS, the negative control), Sunn hemp silage with B. subtilis (SSB), Sunn hemp silage with FJLAB (SSL), and SSB plus FJLAB (SSBL). The results showed the OM content of Sunn hemp silage was decreased $(p<0.05)$, but fiber contents (NDF, ADF, cellulose, and hemicellulose) were increased when compared with fresh Sunn hemp. However, SSL and SSBL could improve nutrition values (higher CP Reduction efficiency; $p<0.01$, decrease cellulose; $p<$ 0.01 , and hemicellulose content; $p<0.10$ ) and quality grading of Sunn hemp silage when compare with the negative control which did not affect to $\mathrm{CP}$ and EE values. Furthermore, FJLAB reduced fiber content and increase CP content of Sunn hemp silage, whereas B. subtilis presented the opposite results. However, the combination of FJLAB and B. subtilis showed the best treatment of Sunn hemp silage of this experiment (the highest CP and EE Reduction efficiency, ruminal gas production, and organic matter degradability; OMD).
\end{abstract}

Keywords: Sunn hemp, Bacillus subtilis, Lactic acid bacteria

\section{Introduction}

In the ruminants' production industry, feed and feeding have a significant impact on farm profitability of livestock farms since feed costs take over $50 \%$ of total cost production in cow/calf production [1] or about $75 \%$ of total variable costs in dairy cows [2]. Therefore, the optimization of feed sources is a means of improving farm profitability [3]. Hence, the utilization of locally available feedstuffs from plant sources becomes crucial for sustainable aquaculture [4].

Sunn hemp (Crotalaria juncea L.) is a tropical legume (C3 plants), widely distributed in the tropics and subtropics, that has incredible potential as a high quality roughage source [5]. Sunn hemp can fix nitrogen from the air as $\mathrm{N}$ sources of protein [6]. It also has a high nutritional value when compared to forage grass [7]. The whole plant of Sunn hemp had sufficient nutritional value for use as a roughage source for ruminants [8]. Sunn hemp contained 15.9 and $57.2 \%$ of Crude protein (CP) and Total Digestible Nutrient (TDN) [9]. As same as other legumes, Sun-hemp seed contains a rich amino acid, starch, ether extract, and calories especially lysine content is greater than other legumes, including soybean [10]. However, anti-nutritional substances including Trypsin inhibitor and alkaloid that are present in the seed could limit its application [4]. Moreover, Sunn hemp seed contains substances high doses of Pyrrolizidine Alkaloids which have toxic effects on ruminants [11]. Therefore, using Sunn hemp as a forage source for ruminants is important to take this toxin into account. Sunn hemp hay (cutting intervals at 50 days) as a roughage source for beef cattle [12], and demonstrated that the supplementation at $50 \%$ in diets was not affecting the productivity of beef cattle. However, southern Thailand is a high rainfall area, the preservation of Sunn hemp as a coarse food source by making Sunn hemp hay is unsuitable, and so Sunn hemp foliage is suitable for preserving as a roughage source for ruminants. In addition, during anaerobic fermentation by microorganisms, the Pyrrolizidine Alkaloids toxins are either completely destroyed or only a small amount remains [13], and reduce toxicity up to $95.5 \%$ [14]. 
An important objective in ensiling forage is to reduce extensive proteolysis, which increases the nutritional losses and leads to affect the quality of silage regarding protein quality and the intake [15]. Successful ensiling process, resulted in a reduced storage loss, preserve a substantial amount of nutrients, and produced edible silage with an ideal dry matter content [16]. During the fermentation process, some problems might appear such as insufficient lactic acid fermentation and a bad smell of silage [17]. The higher the quality of silage prefer the more oxidation during post-opening [18] due to higher levels of residual soluble carbohydrates and lactic acid [16]. The increase in lactic acid content resulted in a reduction of $\mathrm{pH}$ value of the silage and a subsequent restriction in the growth pace of undesirable microbes which are deleterious to the fermentation process [19].

One of the most practices to improve the fermentation process is adding lactic acid bacteria (LAB) which could ensure the appropriate production of lactic acid and decrease the amounts of acetic, butyric, and propionic acid [20]. LAB inoculants have a long history and have been incorporated into silage making as an effective technique to increase lactic acid production [21] to increase the likelihood of getting good preservation of crop nutritive value by reducing plant respiration and enzyme activity and by inhibiting deleterious epiphytic microbial populations [22]. Moreover, some LAB can produce ferulate esterase enzymes during fermentation and increase neutral detergent fiber degradation of the inoculated crop during ensiling [23], which may enhance animal performance when treated silage is fed to ruminants [24]. Hence, Lactic acid bacteria can survive during in vitro ruminal incubation and potentially affect volatile fatty acids (VFA) composition [24,25]. As in previous research, microbial silage inoculants had an effect on in vitro ruminal gas and VFA production [26].

Other than LAB, Bacillus subtilis also produces lactic acid and acetic acid, even though less efficient than LAB at producing lactic acid [27], however, the growth of $B$. subtilis is not suppressed by these fermentation products or by low $\mathrm{pH}$ [15]. Then, the combining of $B$. subtilis with LAB may be an alternative for decreasing fermentation losses and protein degradation through a greater production of lactate and additionally enhancing the aerobic stability of silages [28]. Several studies have shown that both types of inoculant can improve the efficiency of fermentation and the nutritive value of silages [29-31]. Therefore, the objective of this experiment was to investigate the fermentation of Sunn hemp foliage on the ruminal digestibility efficiency in the laboratory.

\section{Materials and methods}

\section{Feed preparation}

The experiment was designed in a Completely Randomized Design (CRD) including 5 dietary treatments: Fresh Sunn hemp (FS; the positive control), Sunn hemp silage (SS; the negative control), Sunn hemp silage with $B$. subtilis (SSB), Sunn hemp silage with FJLAB (SSL) and SSB plus FJLAB (SSBL). Triplicated sets of treatments were prepared by 1,000 $\mathrm{g}$ of fresh Sunn hemp incubated with each culture for 7, 14, and 21 days. Sunn hemp was harvested at the flowering stage (50 days) in an experimental field at the school of Agricultural, Walailak University, Thailand (May 2020). The chemical composition of the Sunn hemp silage was analysed and the control. Samples were dried at $60{ }^{\circ} \mathrm{C}$, ground passes through a 1-mm screen, and then analyzed for dry matter (DM), ash, crude protein (CP), and ether extract (EE) according to [32]. Fiber fractions (neutral detergent fiber; NDF, acid detergent fiber; ADF and acid detergent lignin; ADL) were analyzed according to [33].

Sunn hemp foliage was harvested at the heading stage as same as fresh Sunn hemp and chopped into 1 - 2-cm pieces. Approximately $1,000 \mathrm{~g}$ of the Sunn hemp was mixed with culture at $1 \times 10^{5} \mathrm{CFU} B$. subtilis/g and $1 \%(\mathrm{v} / \mathrm{w})$ of FJLAB. These mixtures were then packed into plastic pouches and sealed with a vacuum packaging machine. The negative control silage was treated with an equivalent amount of sterilized distilled water. B. subtilis (TISTR 25) was stimulated in nutrients broth under the recommendation of the Biodiversity Research Centre (BRC; incubation at $150 \mathrm{rpm}, 30{ }^{\circ} \mathrm{C}$ for $14 \mathrm{~h}$ ). Then culture in nutrients broth at $37^{\circ} \mathrm{C}$ for 5-7 days before [18], and the FJLAB preparation following [34], prepared from Sunn hemp 2 days before foliage making. Twenty-five grams of fresh Sunn hemp was macerated with $50 \mathrm{~mL}$ of distilled water using a blender. The macerate was filtered through a double layer of cheesecloth and the filtrate was put into a 100-mL flask. Approximately $3 \%(\mathrm{w} / \mathrm{v})$ of glucose was added in the filtrates. Molasses was also added to the filtrate to obtain a final concentration of $3 \%$ $(\mathrm{w} / \mathrm{v})$ sucrose. These flasks were shaken well and kept in an incubator for 2 days at $30{ }^{\circ} \mathrm{C}$. At 0 -day, analyzing the concentration of $B$. subtilis by using the optical density (OD) of a $0.5 \mathrm{McF}$ arland standard at $530 \mathrm{~nm}$ and diluted into $1 \times 10^{6} \mathrm{CFU} / \mathrm{mL}$. Fermented $100 \mathrm{~mL}$ of B. subtilis media culture or $10 \mathrm{~mL}$ of FJLAB medium into $1,000 \mathrm{~g}$ of the fresh Sunn hemp, adjusting all Sunn hemp silage to $35 \% \mathrm{DM}$ as follows [35]. 


\section{Sample collection and analysis}

At 7-, 14- and 21-days incubation, the Sunn hemp foliage was estimated the quality grading following silage handbook [36]. The flavor grading was following: strong vinegar (score 12), light vinegar and mind tang (score 8), strong pungent smell (score 4), and rot and fungus smell (score 0). The grading of texture were intact texture as fresh (score 4), minor decomposed and slippery slime (score 2), medium decomposed (score 1), the most decomposed (score 0 ). The color grading was olive-yellow (score 3), olive (score 2), golden brown (score 1), dark brown (score 0 ). The $\mathrm{pH}$ was measured following [36], the $\mathrm{pH}$ grading were 3.5 - 4.5 (score 6), 4.4 - 4.7 (score 4), 4.7 - 5.1 (score 2), > 5.1 (score 0). The total quality grading was following: very good (20 - 25 score), good (15 - 19 score), medium (6 - 14 score), and low (0 - 5 score), respectively. Dietary treatments were analyzed for DM, ash, CP, and EE using the procedure of [32], and measuring the cell wall components (NDF, ADF, and ADL) by the method of [30] by adding heat-stable alpha-amylase with sodium sulfite to remove some starch and nitrogenous matter. Hemicellulose, cellulose, and lignin (NDF-ADF, ADF-ADL, and ADL, respectively) were calculated from the organic matter of the detergent fiber fractions.

\section{In vitro gas production technique}

Three crossbred beef cattle were used as rumen fluid donors. The animals were individually penned, clean freshwater, and mineral blocks were offered as free choice. Rice straw as a roughage was fed on an ad-libitum basis and concentrate (16\% crude protein, $2.4 \mathrm{Mcal} \mathrm{ME} / \mathrm{kg}$ diets) was fed at $1 \%$ body weight in 2 equal portions, at $07.00 \mathrm{am}$ and at $04.00 \mathrm{pm}$. Animals were given the diets for 20 days before the rumen fluid was collected.

This study was conducted by using an in vitro gas technique at various incubation time intervals. $200 \mathrm{mg}$ of feed samples were incubated in $40 \mathrm{~mL}$ serum bottles as described by the procedure of [37]. The rumen fluid and particulate matter were collected before the morning feed from the 2 cattle fed on a roughage diet, homogenized, strained, and filtered through 4 layers of cheesecloth. The glassware was pre-incubated at approximately $39^{\circ} \mathrm{C}$ and flushed with $\mathrm{CO}_{2}$ before use. The rumen fluid (660 mL) was added to warm (about $39^{\circ} \mathrm{C}$ ) and reduced medium consisting of $1,095 \mathrm{~mL}$ distilled water, $730 \mathrm{~mL}$ rumen buffer solution $\left(417 \mathrm{mM} \mathrm{NaHCO}_{3}\right.$ and $51 \mathrm{mM} \mathrm{NH}_{4} \mathrm{HCO}_{3}$ ), $365 \mathrm{~mL}$ macro mineral solution (46 mM $\mathrm{KH}_{2} \mathrm{PO}_{4}, 40 \mathrm{mM} \mathrm{Na} \mathrm{HPO}_{4}, 38 \mathrm{mM} \mathrm{NaCl}$ and $\left.2 \mathrm{mM} \mathrm{MgSO}_{4} \cdot 7 \mathrm{H}_{2} \mathrm{O}\right), 0.23 \mathrm{~mL}$ micro mineral solution $\left(505 \mathrm{mM} \mathrm{MnCl}_{2} \cdot 4 \mathrm{H}_{2} \mathrm{O}, 898 \mathrm{mM} \mathrm{CaCl}_{2} \cdot 2 \mathrm{H}_{2} \mathrm{O}, 42 \mathrm{mM} \mathrm{CoCl} \cdot 6 \mathrm{H}_{2} \mathrm{O}\right.$ and $341 \mathrm{mM} \mathrm{FeCl} \mathrm{m}_{2} \cdot 6 \mathrm{H}_{2} \mathrm{O}$ ), 1 $\mathrm{mL}$ of $4 \mathrm{mM}$ resazurin and $60 \mathrm{~mL}$ freshly prepared reduction solution containing $145 \mathrm{mM} \mathrm{Na}_{2} \mathrm{~S} \cdot 9 \mathrm{H}_{2} \mathrm{O}$ and $3.7 \mathrm{~mL} 1 \mathrm{M}-\mathrm{NaOH}$. The mixture was kept at $39{ }^{\circ} \mathrm{C}$ under stirring with $\mathrm{CO}_{2}$ by using a magnetic stirrer fitted with a hot plate. Approximately $40 \mathrm{~mL}$ of the rumen-fluid medium was transferred into each syringe and incubated in an incubator at $39^{\circ} \mathrm{C}$.

The gas production was recorded at $0,1,2,4,6,8,12,18,24,48,72$ and $96 \mathrm{~h}$ of incubation. Cumulative gas production data were fitted to the model as follow [38],

$\mathrm{Y}=\mathrm{a}+\mathrm{b}\left(1-\mathrm{e}^{-\mathrm{ct}}\right)$

where $\mathrm{a}=$ the water soluble and instantly degradable fraction, $\mathrm{b}=$ the gas production from the insoluble fraction, $\mathrm{c}=$ the gas production rate constant for the insoluble fraction $(\mathrm{b}), \mathrm{t}=$ incubation time, $(\mathrm{a}+\mathrm{b})=$ the potential extent of gas production, $\mathrm{y}=$ gas production at time ' $\mathrm{t}$ '. Effective degradability (ED) was estimated following the model: $\mathrm{ED}=\mathrm{a}+[\mathrm{bc} /(\mathrm{k}+\mathrm{c})]$, where $\mathrm{k}$ is the passage rate from the rumen, estimated to be $5 \% / \mathrm{h}$ [39]. Rumen fluid samples were then filtered through 4 layers of cheesecloth. Samples were divided into 2 portions; the $1^{\text {st }}$ portion was used for ammonia-nitrogen $\left(\mathrm{NH}_{3}-\mathrm{N}\right)$ analysis using the Kjeldahl methods [32] and VFA analysis using HPLC [40]. The $24 \mathrm{~h}$ gas production were used to calculated of metabolizable energy (ME) by the following equation [37]: Metabolizable energy (ME, $\mathrm{MJ} / \mathrm{Kg} \mathrm{DM})=2.20+0.136 \mathrm{Gv}+0.057 \mathrm{CP}+0.0029 \mathrm{CF}$, where $\mathrm{Gv}=$ net gas production $(24 \mathrm{~h}$ postincubation; $\mathrm{mL} / 200 \mathrm{mg}), \mathrm{CP}=$ crude protein, $\mathrm{CF}=$ ether extract

At 24 and $48 \mathrm{~h}$ post-inoculation, duplicate bottles for each treatment were determined in vitro true digestibility according to [38] by filtered through the Gooch crucibles then dried at $105^{\circ} \mathrm{C}$ for $24 \mathrm{~h}$, after which dry sample weight was recorded. An in vitro DM and OM digestibility (IVDMD, IVOMD) was calculated as:

$\operatorname{IVDMD}(\%)=[(\mathrm{DMi}-\mathrm{DMr}) / \mathrm{DMi}] \times 100$

IVOMD $(\%)=[(\mathrm{OMi}-\mathrm{OMr}) / \mathrm{OMi}] \times 100$,

Where $\mathrm{DMi} / \mathrm{OMi}$ is the initial DM/OM weight of the samples before the inoculation and $\mathrm{DMr} / \mathrm{OMr}$ is the residual DM/OM weight of the samples post- inoculation 


\section{Statistical analysis}

All obtained data were subjected to the Analysis of Variance (ANOVA) procedures according to a $2 \times 2$ augmented factorial arrangement in CRD. Means were statistically compared using Tukey Test.

\section{Results and discussion}

\section{The quality of Sunn hemp silage}

The $\mathrm{pH}$ of Sunn hemp silage at 21 days post-fermentation ranged from 4.3 to 5.45 (Figure 1). The $\mathrm{pH}$ value of SSL and SSBL is lower than the control, however, SSB is higher than the control. This result agrees with reporting by [27], FJLAB is more productive on lactic acid production than $B$. subtilis, then offering more efficiency on the $\mathrm{pH}$ reduction.

AS same as $\mathrm{pH}$ value, the physical evaluation of the various microbial fermented procedure. It was found that the SS, SSB, SSL, and SSBL were found to have fermentation characteristics according to the fermented feed plant standard [36]. All Sunn hemp silage presented the same grading of flavor (mild odor of vinegar), texture (the leaves and stems remain intact), and color (green-yellow), however, SSL and SSBLL have the best quality of $\mathrm{pH}$ grading (Table 1 and Figure 2). These results have confirmed the reporting of [18] that $\mathrm{pH}$ values highly impact silage quality. In the case of higher $\mathrm{pH}$ value of SSB (5.45) than other treatment $(4.95,4.55$, and 4.45 in SS, SSL, and SSBL, respectively), but still under the accepted standard of silage quality by the [36]. These results in an imbalance of the fermentation system, with a slippery texture when touched due to the growth of Clostridium bacteria (grown well in fermentation plants with high humidity or slow acid production [41]. The Clostridium spp. is a butyric acid producer from lactic acids, as a result, the silage has a high $\mathrm{pH}$, pungent smell, and slippery slime, also a rapid decrease in $\mathrm{pH}$ inhibits clostridial fermentation and hydrolysis of plant proteins by plant enzymes [42], who described that, since when clostridia ferment amino acids, ammonia production increases the $\mathrm{pH}$, and other undesirable products may accumulate [43].

\section{$\square \mathrm{SS} \otimes \mathrm{SSB} \boxplus \mathrm{SSL} \boxminus \mathrm{SSBL}$}

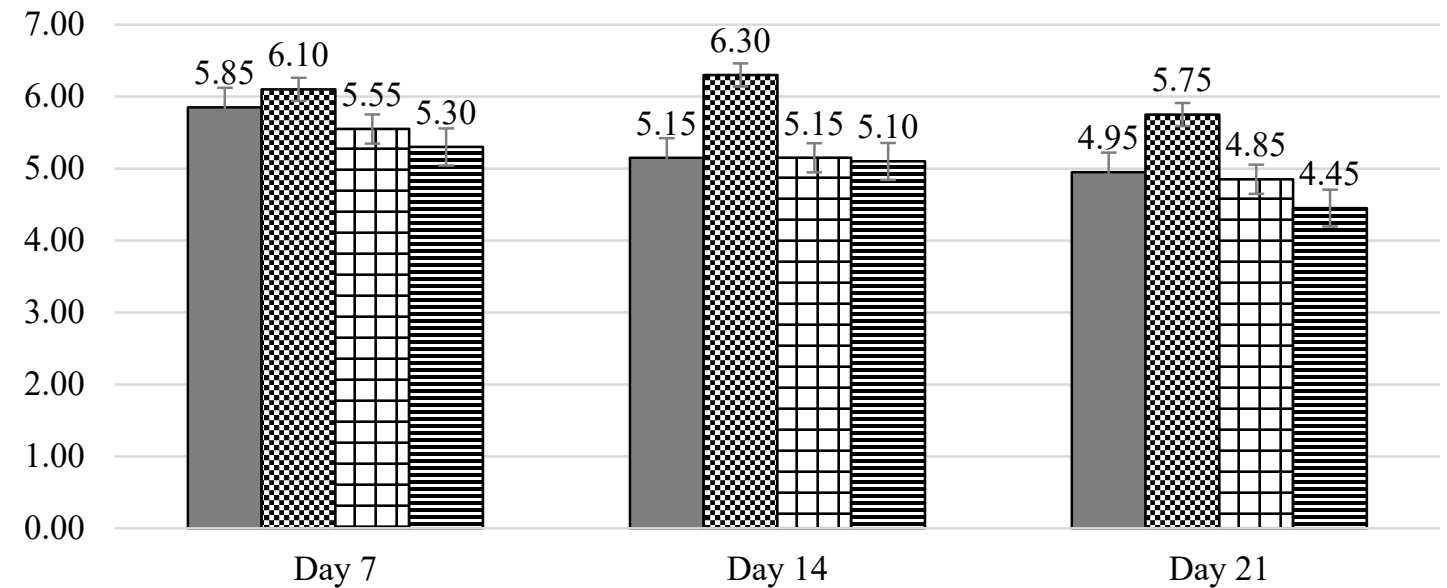

Figure $1 \mathrm{pH}$ level of Sunn hemp foliage, SS = Sunn hemp silage, SSB = Sunn hemp silage with $B$. subtilis, SSL = Sunn hemp silage with FJLAB, SSBL = SSB with FJLAB. 
Table 1 The quality grading of Sunn hemp foliage.

\begin{tabular}{|c|c|c|c|c|c|c|c|}
\hline \multirow{2}{*}{ Items } & \multicolumn{2}{|c|}{ No FJLAB } & \multicolumn{2}{|c|}{ With FJLAB } & \multirow{2}{*}{$p$-value } & \multicolumn{2}{|c|}{ Contrast } \\
\hline & SS & SSB & SSL & SSBL & & No vs BS & No vs FJLAB \\
\hline \multicolumn{8}{|l|}{ Quality grading } \\
\hline Flavor & 8 & 8 & 8 & 8 & & & \\
\hline Texture & 4 & 4 & 4 & 4 & & & \\
\hline Color & 2 & 2 & 2 & 2 & & & \\
\hline $\mathrm{pH}$ & 2 & 0 & 4 & 4 & & & \\
\hline Grading Score & Good & medium & Good & Good & & & \\
\hline \multicolumn{8}{|l|}{$\mathrm{pH}$} \\
\hline 7 days & $5.85^{\mathrm{a} \mathrm{a}^{* *}}$ & $6.10^{\mathrm{b} * *}$ & $5.55^{\mathrm{a}^{*}}$ & $5.30^{\mathrm{a}^{*}}$ & 0.04 & 1.00 & 0.01 \\
\hline 14 days & $5.15^{\mathrm{aA} * *}$ & $6.30^{\mathrm{bB} * *}$ & $5.15^{\mathrm{aA}^{*}}$ & $5.10^{\mathrm{aB} *}$ & 0.01 & 0.02 & 0.01 \\
\hline 21 days & $4.95^{* *}$ & $5.75^{* *}$ & $4.55^{*}$ & $4.45^{*}$ & 0.09 & 0.27 & 0.03 \\
\hline
\end{tabular}

${ }^{\mathrm{ab}}$ Values in the same row with different superscripts differ of treatment. ${ }^{\mathrm{AB}}$ Values in the same row with different superscripts differ of $B$. subtilis supplementation. ${ }^{*, * *}$ Values in the same row with different superscripts differ of FJLAB supplementation.

$\mathrm{BS}=$ B. subtilis, FJLAB $=$ Fermented juice of epiphytic lactic acid bacteria.

$\mathrm{SS}=$ Sunn hemp silage, $\mathrm{SSB}=$ Sunn hemp silage with $B$. subtilis, $\mathrm{SSL}=$ Sunn hemp silage with FJLAB, $\mathrm{SSBL}=\mathrm{SSB}$ with FJLAB.

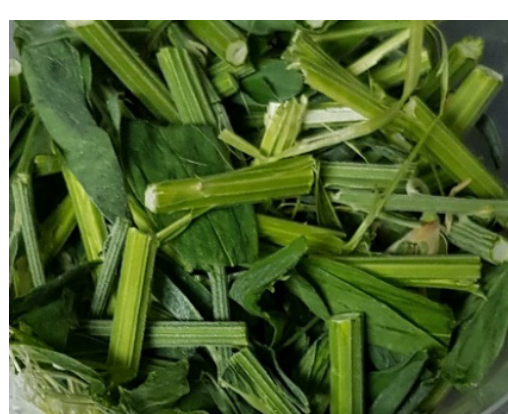

FS

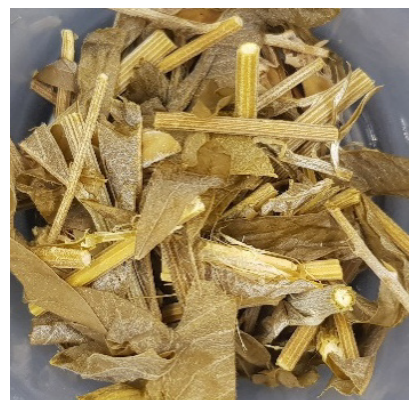

SS

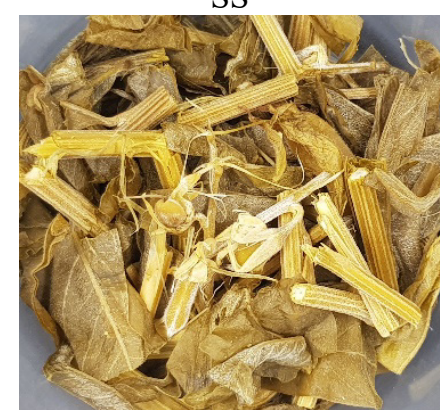

SSB

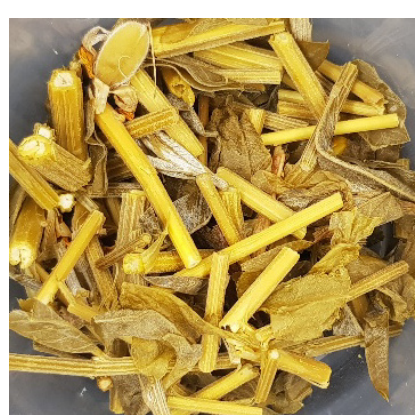

SSL

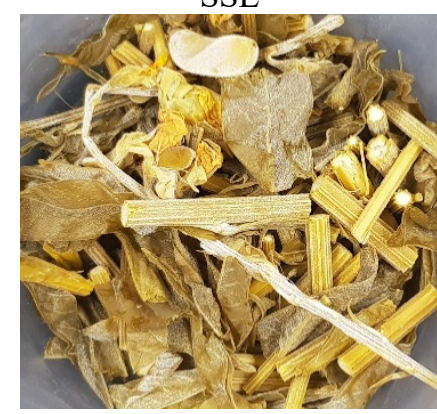

SSBL

Figure 2 Physical texture of Sunn hemp foliage. FS = Fresh Sunn hemp, SS = Sunn hemp silage,

$\mathrm{SSB}=$ Sunn hemp silage with $B$. subtilis, SSL = Sunn hemp silage with FJLAB, SSBL $=$ SSB with FJLAB.

\section{Chemical composition of Sunn hemp}

We hypothesize that B. subtilis and FJLAB supplementation would preserve nutrient content; and based on the results, the percentages of CP and EE were not affected by any treatment. These results agree with the quality of Sunn hemp silage, which the majority of Sunn hemp silage is in good quality 
that the lactic acids products of all treatment are sufficient for restriction in the growth pace of undesirable microbes in fermentation chambers [19] and preserve a substantial amount of nutrients [16].

The main stages of nutrient losses are field harvesting, silo respiration and fermentation, effluent production, and oxygen exposure during storage and feed-out phases and the minimum value of the DM losses will occur in good management processing [44]. The losing percentage could rise to $70 \%$ of the stored DM in the peripheral areas and near the sidewalls of the bunkers and are related to the depletion of the digestible carbohydrate and organic acid fractions [45], and silage that has spoiled because of exposure to air is undesirable, due to the lower nutritive value, short proliferation and to the risk of negative effects on animal performance [46]. Thus, exposure to aerobic fermentation is a very important factor in subsequent nutritional quality and feeding value [26]. The stability of silages against aerobic deterioration, LAB is faster lactic acid producer and sufficient to improve the stability of silages via the anaerobic degradation [47].

However, Sunn hemp foliage shows in decreasing of OM content, but NDF, ADF, ADL, and cellulose were increased when compared with fresh Sunn hemp. This is also due to aerobic fermentation of silage stage leading to digestible nutrients loss and affecting to increase the fiber content of Sunn hemp silage. In the same way, OM and fiber content are vary by B. subtilis and FJLAB supplementation (Table 2 and Figure 3). The OM content of fresh Sunn hemp (94.36\%) is higher than SSB (92.08\%), but not significantly different from SS, SSL and SSBL ( $p>0.05 ; 92.97,93.19$ and 93.06, respectively). This could be due to the lactic acid-producing efficiency of $B$. subtilis was less than LAB [27], making a slower $\mathrm{pH}$ value decreasing and more nutrient loss in anaerobic fermentation of silage.

The NDF and ADF content were influenced by B. subtilis addition, on the other hand, CP content were decreased by $B$. subtilis supplementation. this result could be due to the low efficiency of lactic acid production of $B$. subtilis leading to insufficient optimizing $\mathrm{pH}$ in silage and leading to nutrient loss during anaerobic fermentation system. Whereas, FJLAB affected to increase the percentation of CP and hemicellulose, but decrease NDF, ADF, and cellulose content. The percentage of NDF, ADF, and cellulose of FJLAB supplementation was higher than No supplementation. FJLAB supplementation affected to decrease $\mathrm{pH}$ level and improve the quality of Sunn hemp silage. In addition, SSL and SSBL showed higher cellulose and hemicellulose content than SS, showing that FJLAB increased the percentage of rumen fermentable fiber of Sunn hemp silage. In the same way, the chemical composition improvement of lactic acid producer culture in Sunn hemp silage is promising in SSBL.

\section{CRUDE PROTEIN}
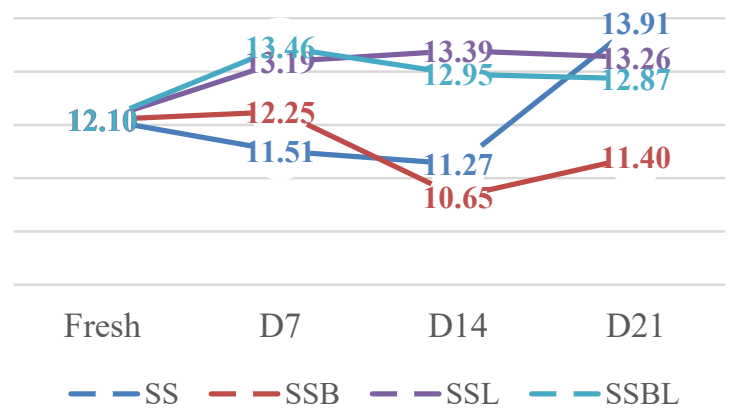

\section{ETHER EXTRACT}

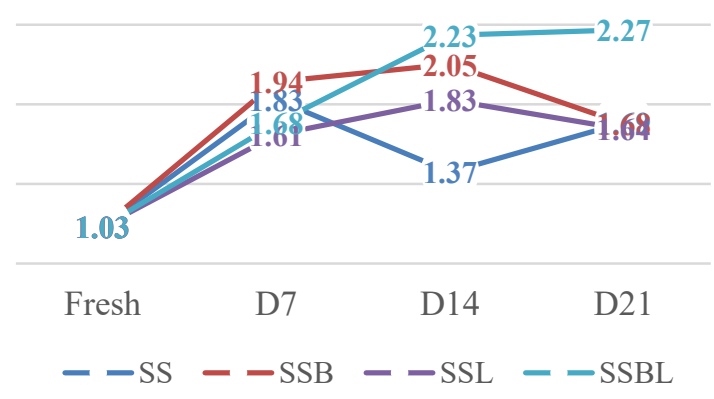

a)

b) 


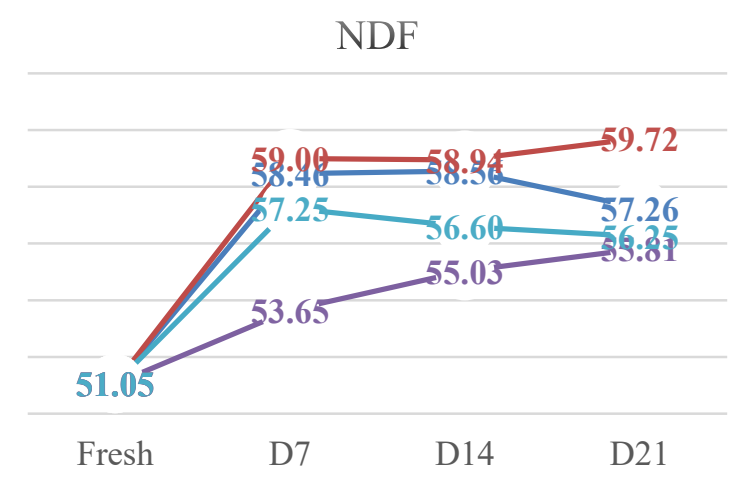

c)

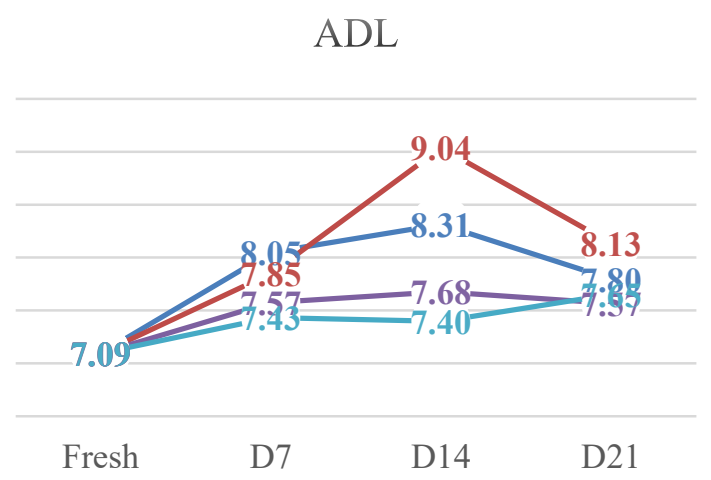

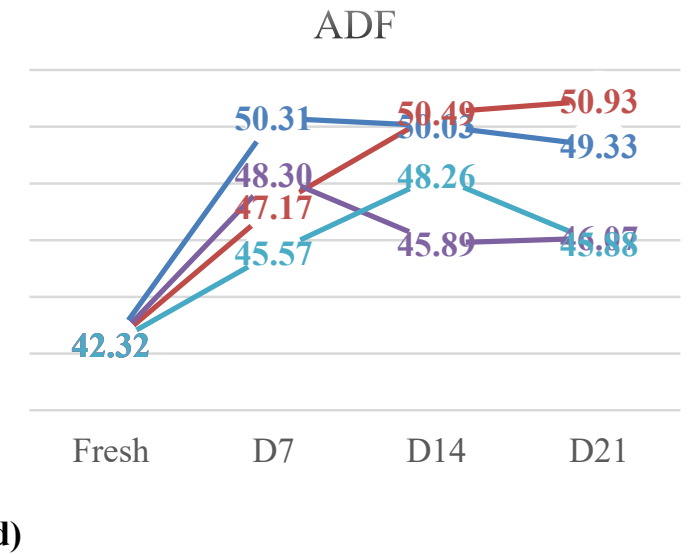

d)

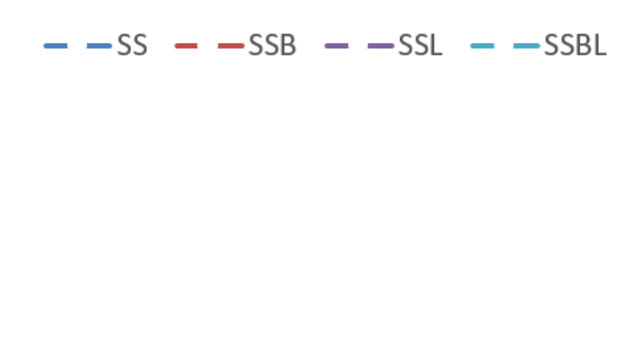

e)

Figure 3 The comparisons of Nutrients content of Sunn hemp silage with fresh Sunn hemp on the different fermentation days (7, 14 and 21 days). a) crude protein, b) ether extract, c) neutral detergent fiber, d) acid detergent fiber, e) acid detergent lignin. FS = Fresh Sunn hemp, SS = Sunn hemp silage, SSB $=$ Sunn hemp silage with $B$. subtilis, SSL = Sunn hemp silage with FJLAB, SSBL $=$ SSB with FJLAB.

Table 2 The chemical composition of fresh Sunn hemp and Sunn hemp silage.

\begin{tabular}{|c|c|c|c|c|c|c|c|c|c|}
\hline \multirow[b]{2}{*}{ Items } & \multirow[b]{2}{*}{ FS } & \multicolumn{2}{|c|}{ No FJLAB } & \multicolumn{2}{|c|}{ With FJLAB } & \multirow[t]{2}{*}{$p$-value } & \multicolumn{3}{|c|}{ Contrast } \\
\hline & & SS & SSB & SSL & SSBL & & $\begin{array}{c}\text { FS } \\
v s \\
\text { Silage }\end{array}$ & $\begin{array}{c}\text { No } \\
\text { vS } \\
\text { BS }\end{array}$ & $\begin{array}{c}\text { No } \\
\text { vs } \\
\text { FJLAB }\end{array}$ \\
\hline DM & $89.73^{\mathrm{a} 1}$ & $89.82^{\mathrm{a} 2 \mathrm{~A}^{*}}$ & $90.38^{\mathrm{b} 2 \mathrm{~B}^{*}}$ & $91.18^{\mathrm{c} 2 \mathrm{~A}^{* *}}$ & $91.58^{\mathrm{d} 2 \mathrm{~B}^{* *}}$ & $<0.01$ & $<0.01$ & $<0.01$ & $<0.01$ \\
\hline $\mathrm{OM}$ & $94.39^{\mathrm{b} 2}$ & $92.97^{\mathrm{ab} 1}$ & $92.08^{\mathrm{a} 1}$ & $93.19^{\mathrm{ab} 1}$ & $93.06^{\mathrm{ab} 1}$ & 0.01 & $<0.01$ & 0.10 & 0.66 \\
\hline $\mathrm{CP}$ & 12.10 & $13.91^{\mathrm{B}^{*}}$ & $11.40^{\mathrm{A}^{*}}$ & $13.26^{\mathrm{B}^{* *}}$ & $12.87^{\mathrm{A}^{* *}}$ & 0.07 & 0.21 & $<0.01$ & $<0.01$ \\
\hline $\mathrm{EE}$ & 1.03 & 1.69 & 1.68 & 1.64 & 2.27 & 0.20 & 0.06 & 0.34 & 0.38 \\
\hline $\mathrm{NDF}$ & $51.05^{\mathrm{a} 1}$ & $57.26^{\mathrm{b} 2 \mathrm{~A}^{* *}}$ & $59.72^{\mathrm{c} 2 \mathrm{~B}^{* *}}$ & $55.8^{\mathrm{b} 2 \mathrm{~A}^{*}}$ & $56.25^{\mathrm{b} 2 \mathrm{~B}^{*}}$ & $<0.01$ & $<0.01$ & $<0.01$ & $<0.01$ \\
\hline $\mathrm{ADF}$ & $42.32^{\mathrm{a} 1}$ & $49.33^{\mathrm{c} 2 \mathrm{~A}^{* *}}$ & $50.93^{\mathrm{d} 2 \mathrm{~B}^{* *}}$ & $46.07^{\mathrm{b} 2 \mathrm{~A}^{*}}$ & $45.88^{\mathrm{b} 2 \mathrm{~B}^{*}}$ & $<0.01$ & $<0.01$ & $<0.01$ & $<0.01$ \\
\hline $\mathrm{ADL}$ & $7.09^{\mathrm{a} 1}$ & $7.80^{\mathrm{ab} 2}$ & $8.13^{\mathrm{b} 2}$ & $7.57^{\mathrm{ab} 2}$ & $7.65^{\mathrm{ab} 2}$ & 0.03 & 0.01 & 0.23 & 0.06 \\
\hline Hemicellulose & $8.73^{\mathrm{ab}}$ & $7.93^{\mathrm{a}^{*}}$ & $8.79^{a b^{*}}$ & $9.74^{b * *}$ & $10.37^{b^{* *}}$ & 0.01 & 0.23 & 0.06 & $<0.01$ \\
\hline Cellulose & $35.23^{\mathrm{a} 1}$ & $41.53^{\mathrm{c} 2^{* *}}$ & $42.79^{\mathrm{c} 2^{* *}}$ & $38.51^{\mathrm{b} 2^{*}}$ & $38.23^{\mathrm{b} 2^{*}}$ & $<0.01$ & 0.02 & 0.09 & $<0.01$ \\
\hline
\end{tabular}

${ }^{\text {abcd }}$ Values in the same row with different superscripts differ of treatment. ${ }^{12}$ Values in the same row with different superscripts differ of silage. ${ }^{\mathrm{AB}}$ Values in the same row with different superscripts differ of $B$. subtilis supplementation. ${ }^{* * *}$ Values in the same row with different superscripts differ of FJLAB supplementation. $\mathrm{BS}=$ B. subtilis, $\mathrm{FJLAB}=$ Fermented juice of epiphytic lactic acid bacteria.

FS = Fresh Sunn hemp, SS = Sunn hemp silage, SSB = Sunn hemp silage with $B$. subtilis, SSL = Sunn hemp silage with FJLAB, SSBL = SSB with FJLAB. 
Table 3 The nutrients reduction efficiency (\%) of Sunn hemp silage.

\begin{tabular}{|c|c|c|c|c|c|c|c|}
\hline \multirow{2}{*}{ Items } & \multicolumn{2}{|c|}{ No FJLAB } & \multicolumn{2}{|c|}{ With FJLAB } & \multirow{2}{*}{$p$-value } & \multicolumn{2}{|c|}{ Contrast } \\
\hline & SS & SSB & SSL & SSBL & & No vs BS & No vs LAB \\
\hline OM, \% & $-0.86^{\mathrm{ab*}}$ & $-1.30^{\mathrm{a}^{*}}$ & $-0.55^{\mathrm{b} * *}$ & $-0.51^{\mathrm{b} * *}$ & $<0.01$ & 0.12 & $<0.01$ \\
\hline $\mathrm{CP}, \%$ & $1.07^{\mathrm{ab} *}$ & $-5.49^{\mathrm{a}^{*}}$ & $8.22^{\mathrm{ab} * *}$ & $9.76^{\mathrm{b} * *}$ & $<0.01$ & 0.18 & $<0.01$ \\
\hline $\mathrm{EE}, \%$ & 63.36 & 62.58 & 59.32 & 119.86 & 0.18 & 0.44 & 0.43 \\
\hline NDF, $\%$ & $13.78^{\mathrm{bcA} A^{* *}}$ & $15.99^{\mathrm{cB}^{* *}}$ & $7.40^{\mathrm{aA} *}$ & $11.06^{\mathrm{bB} *}$ & $<0.01$ & $<0.01$ & $<0.01$ \\
\hline $\mathrm{ADF}, \%$ & $117.88^{\mathrm{c} * *}$ & $117.03^{\mathrm{bc} * *}$ & $110.48^{\mathrm{ab} *}$ & $110.03^{\mathrm{a}^{*}}$ & $<0.01$ & 0.63 & $<0.01$ \\
\hline ADL, $\%$ & $115.39^{\mathrm{a}}$ & $120.37^{b}$ & $111.98^{\mathrm{a}}$ & $113.25^{\mathrm{a}}$ & 0.21 & 0.13 & 0.90 \\
\hline Hemicellulose, \% & $-9.21^{\mathrm{A}}$ & $0.68^{\mathrm{B}}$ & $11.54^{\mathrm{A}}$ & $18.74^{\mathrm{B}}$ & 0.08 & 0.01 & 0.81 \\
\hline Cellulose, $\%$ & $18.76^{\mathrm{b} *}$ & $16.92^{\mathrm{ab} *}$ & $11.14^{\mathrm{a} * *}$ & $10.92^{\mathrm{a}^{* *}}$ & $<0.01$ & 0.50 & $<0.01$ \\
\hline
\end{tabular}

${ }^{\mathrm{abc}}$ Values in the same row with different superscripts differ of treatment. ${ }^{\mathrm{AB}}$ Values in the same row with different superscripts differ of B. subtilis supplementation. ${ }^{*, * *}$ Values in the same row with different superscripts differ of FJLAB supplementation.

$\mathrm{BS}=$ B. subtilis, $\mathrm{FJLAB}=$ Fermented juice of epiphytic lactic acid bacteria

FS $=$ Fresh Sunn hemp, SS = Sunn hemp silage, $\mathrm{SSB}=$ Sunn hemp silage with $B$. subtilis, $\mathrm{SSL}=$ Sunn hemp silage with FJLAB, SSBL = SSB with FJLAB.

\section{In vitro gas production, gas characteristic, rumen fermentation, and digestibility}

Cumulative gas volumes after incubation are shown in Figure 4, and the parameters of the gas characteristics are presented in Table 4. The water-soluble and instantly degradable fraction (a), the fermentation of the insoluble fraction (b), the rates of gas production (c), and total gas production (d) were not different among treatments, however, effective gas production potential (EP) of FS (49.93) and SSBL (50.03) are significantly higher $(p<0.05)$ than SS, SSB and SSL $(35.47,37.40$ and 29.34, respectively).

This result agrees with that obtained by Phillip and Fellner [28], who indicated that the combining of $B$. subtilis with FJLAB have an alternative for decreasing fermentation losses and protein degradation through greater production of lactate and 2 types of inoculant can improve the efficiency of fermentation and the nutritive value of silages more than one culture supplementation [29-31]. This could be due to the LAB having an effect on the release of soluble carbohydrates or as complex as the removal of structural barriers that limit the microbial digestion of feed in the rumen [48], resulting in an increase in feed utilization and gas production.

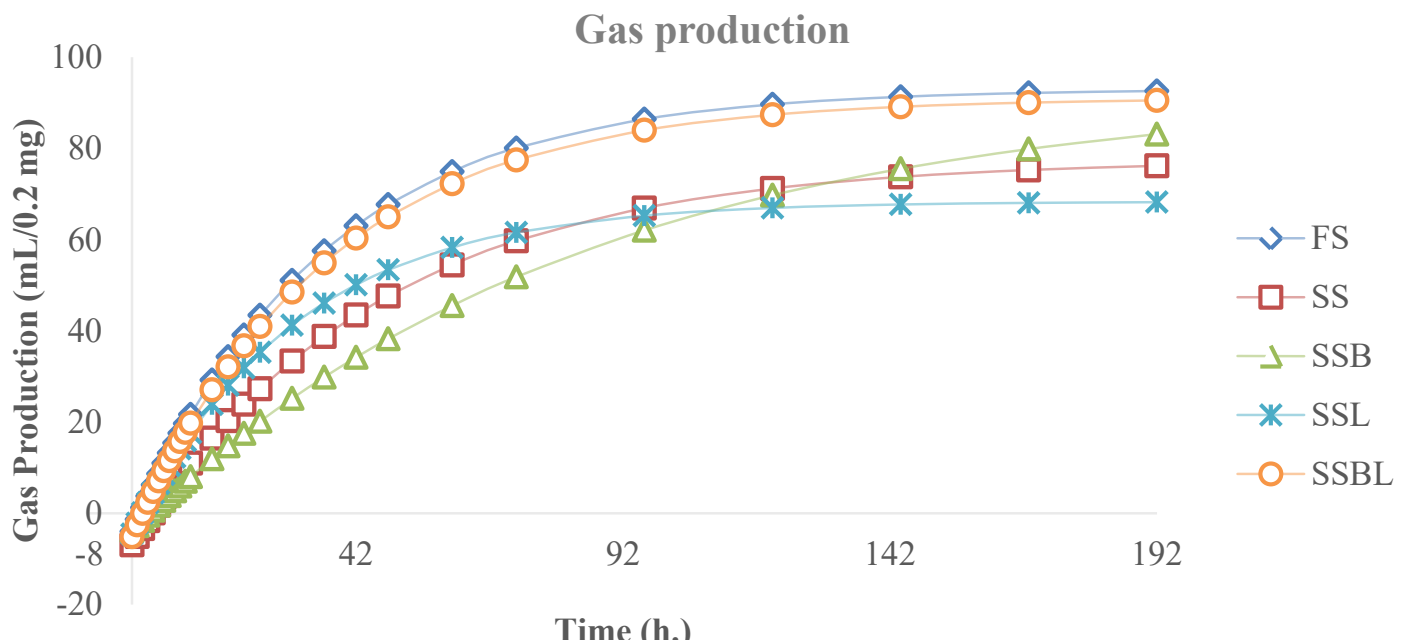

Figure 4 in vitro gas production of Sunn hemp foliage. FS = Fresh Sunn hemp, SS = Sunn hemp silage, $\mathrm{SSB}=$ Sunn hemp silage with $B$. subtilis, $\mathrm{SSL}=$ Sunn hemp silage with FJLAB, SSBL = SSB with FJLAB. 
Table 4 The gas efficiency of fresh Sunn hemp and Sunn hemp silage.

\begin{tabular}{|c|c|c|c|c|c|c|c|c|c|}
\hline \multirow[b]{2}{*}{ Items } & \multirow[b]{2}{*}{ FS } & \multicolumn{2}{|c|}{ No FJLAB } & \multicolumn{2}{|c|}{ With FJLAB } & \multirow[b]{2}{*}{$p$-value } & \multicolumn{3}{|c|}{ Contrast } \\
\hline & & SS & SSB & SSL & SSBL & & $\begin{array}{c}\text { FS } \\
v s \\
\text { Silage }\end{array}$ & $\begin{array}{c}\text { No } \\
v s \\
\text { BS }\end{array}$ & $\begin{array}{c}\text { No } \\
v s \\
\text { FJLAB }\end{array}$ \\
\hline $\mathrm{a}$ & -4.00 & -6.89 & -4.56 & -3.83 & -5.11 & 0.11 & 0.22 & 0.16 & 0.55 \\
\hline $\mathrm{b}$ & 97.06 & $84.41^{\mathrm{B}}$ & $72.91^{\mathrm{A}}$ & $96.91^{\mathrm{B}}$ & $96.16^{\mathrm{A}}$ & 0.16 & 0.25 & 0.03 & 0.45 \\
\hline $\mathrm{c}$ & $0.02^{\mathrm{ab}}$ & $0.02^{\mathrm{ab*}}$ & $0.03^{b^{*}}$ & $0.01^{\mathrm{a}^{* *}}$ & $0.02^{\mathrm{ab} * *}$ & $<0.01$ & 0.17 & 0.31 & $<0.01$ \\
\hline $\mathrm{d}$ & 101.14 & 91.30 & 77.47 & 100.75 & 101.28 & 0.22 & 0.32 & 0.05 & 0.43 \\
\hline ED & $49.93^{\mathrm{b} 2}$ & $35.47^{\mathrm{ab} 1^{*}}$ & $37.40^{\mathrm{ab} 1^{*}}$ & $29.34^{\mathrm{a} 1^{* *}}$ & $50.03^{\mathrm{b} 1^{* *}}$ & $<0.01$ & $<0.01$ & 0.36 & $<0.01$ \\
\hline
\end{tabular}

${ }^{\text {abcd }}$ Values in the same row with different superscripts differ of treatment. ${ }^{12}$ Values in the same row with different superscripts differ of silage. ${ }^{\mathrm{AB}}$ Values in the same row with different superscripts differ of $B$. subtilis supplementation ${ }^{*, * *}$ Values in the same row with different superscripts differ of FJLAB supplementation.

$\mathrm{BS}=$ B. subtilis, $\mathrm{FJLAB}=$ Fermented juice of epiphytic lactic acid bacteria

FS = Fresh Sunn hemp, SS = Sunn hemp silage, $\mathrm{SSB}=$ Sunn hemp silage with $B$. subtilis, $\mathrm{SSL}=$ Sunn hemp silage with FJLAB, SSBL = SSB with FJLAB.

Table 5 The ruminal fermentation of fresh Sunn hemp and Sunn hemp silage.

\begin{tabular}{|c|c|c|c|c|c|c|c|c|c|}
\hline \multirow[b]{2}{*}{ Items } & \multirow[b]{2}{*}{ FS } & \multicolumn{2}{|c|}{ No FJLAB } & \multicolumn{2}{|c|}{ With FJLAB } & \multirow[b]{2}{*}{$p$-value } & \multicolumn{3}{|c|}{ Contrast } \\
\hline & & SS & SSB & SSL & SSBL & & $\begin{array}{c}\text { FS } \\
v s \\
\text { Silage } \\
\end{array}$ & $\begin{array}{c}\text { No } \\
v s \\
\text { BS } \\
\end{array}$ & $\begin{array}{c}\text { No } \\
v s \\
\text { FJLAB } \\
\end{array}$ \\
\hline \multicolumn{10}{|c|}{ Volatile fatty acids (VFAs) } \\
\hline $\mathrm{c} 2, \%$ & 70.95 & 71.89 & 70.85 & 70.33 & 70.90 & 0.41 & 0.97 & 0.57 & 0.39 \\
\hline $\mathrm{c} 3, \%$ & 20.63 & 19.94 & 20.97 & 21.54 & 20.76 & 0.42 & 0.91 & 0.63 & 0.45 \\
\hline $\mathrm{c} 4, \%$ & 8.41 & 8.16 & 8.16 & 8.125 & 8.32 & 0.86 & 0.56 & 0.85 & 0.68 \\
\hline Total, mmol & 114.08 & 96.60 & 97.94 & 119.10 & 105.02 & 0.29 & 0.48 & 0.22 & 0.91 \\
\hline \multicolumn{10}{|l|}{ In vitro digestibility } \\
\hline IVDMD, $\%$ & 80.62 & 78.90 & 76.77 & 76.27 & 75.87 & 0.12 & 0.01 & 0.17 & 0.46 \\
\hline IVOMD, \% & 78.35 & 73.80 & 74.12 & 77.87 & 80.92 & 0.54 & 0.66 & 0.12 & 0.66 \\
\hline ME (Mcal/kg) & 3.00 & 2.82 & 2.85 & 3.00 & 3.07 & 0.56 & 0.65 & 0.12 & 0.69 \\
\hline TDN, $\%$ & 82.25 & 77.52 & 77.82 & 81.77 & 85.00 & 0.54 & 0.66 & 0.12 & 0.66 \\
\hline
\end{tabular}

$\mathrm{BS}=B$. subtilis, FJLAB $=$ Fermented juice of epiphytic lactic acid bacteria.

FS = Fresh Sunn hemp, SS = Sunn hemp silage, SSB = Sunn hemp silage with B. subtilis, SSL = Sunn hemp silage with FJLAB, SSBL $=$ SSB with FJLAB.

As can be seen from Table 5, the volatile fatty acids production, in vitro digestibility of DM and $\mathrm{OM}$, metabolizable energy (ME), and total digestible nutrients (TDN) were not significantly different among treatments. The ruminal fermentation products do not have any effect by all treatments, these results mean that the replacement of fresh Sunn hemp by Sunn hemp silage is practical in ruminants.

\section{Conclusions}

The quality (both chemical of degradation efficiency) of Sunn hemp silage as a roughage source for ruminants is lower than fresh Sunn hemp, however, FJLAB could improve $\mathrm{pH}$ grading, CP, and fiber percentage of Sunn hemp. Moreover, SSBL is the best promising treatment to improve the quality of Sunn hemp silage when compared with the others and presented the same value of effective degradability as fresh Sunn hemp. 


\section{Acknowledgements} support.

The authors would like to express heartfelt thanks to Walailak University for financial and facilities

\section{References}

[1] R Ramsey, D Doye, C Ward, J McGrann, L Falconer and S Bevers. Factors affecting beef cow her costs production and profits. J. Agric. Appl. Econ. 2005; 37, 91-9.

[2] L Connolly, A Kinsella, G Quinlan and B Moran. National farm survey 2008. Teagasc, Republic of Ireland, 2010, p. 104

[3] L Shalloo, P Dillon, M Rath and M Wallace. Description and validation of the Moorepark dairy system model. Int. J. Dairy Sci. 2004; 87, 1945-59.

[4] MO Lawal, AZ Aderolu, B Adeyemi and OO Aarode. Dietary effects of Sun-hemp (Crotalaria juncea Linn.) in the diet of African catfish, Clarias gariepinus juveniles. Acta SATECH. 2013; 4, 108-18.

[5] K Janardhanan, V Vadivel and M Pugalenthi. Biodiversity in Indian underexploited/tribal pulses. In: PK Jaiwal and RP Singh (Eds.). Improvement strategies for Leguminosae biotechnology. Kluwer Academic Publishers, Amsterdam, The Netherlands. 2003, p. 353-405.

[6] MO Lawal, AZ Aderolu, B Adeyemi and OO Aarode. Dietary effects of Sun-hemp (Crotalaria juncea Linn.) in the diet of African catfish, Clarias gariepinus juveniles. Acta SATECH. 2013; 4, 108-18.

[7] J Fraser, D McCartney, H Najda and Z Mir. Yield potential and forage quality of annual forage legumes in South Alberta and Northeast Saskatchewan. Can. J. Plant Sci. 2004; 84, 143-55.

[8] Z Mansoer, DW Reeves and CW Wood. Suitability of Sunn hemp as an alternative late-summer legume cover crop. Soil Sci. Soc. Am. J. 1997; 61, 246-53.

[9] PL Sherasia, MR Garg, BT Phondba and SA Hossain. Estimation of metabolizable energy, net energy-lactation and total digestible nutrients of some ruminant feedstuffs using in vitro gas production technique. Indian J. Dairy Sci. 2015; 68, 370-5.

[10] P Dhan, PN Mishra and PS Mishra. Amino acid profile of winged bean (Psophocarpus tetragonolobus (L.). DC: A rich source of vegetable protein. Plant Foods Hum. Nutr. 1987; 37, 261-4.

[11] European Food Safety Authority. Opinion of the scientific panel on contaminants in the food chain on a request from the European commission related to pyrrolizidine alkaloids as undesirable substances in animal feed. EFSA J. 2007; 447, 1-51.

[12] P Lounglawan and W Suksombat. Utilization of sunnhemp meal in beef cattle diet. Research report. Suranaree University of Technology, Thailand. 2015, p. 48.

[13] P Mulder, B Beumer, E Oosterink and JD Jong. Dutch survey pyrrolizidine alkaloids in animal forage. RIKILT-Institute of Food Safety, Wageningen University \& Research Centre, The Netherlands. 2009, p. 45

[14] U Candrian, J Lüthy, P Schmid, C Schlatter and E Gallasz. Stability of pyrrolizidine alkaloids in hay and silage. J. Agric. Food Chem. 1984; 32, 935-7.

[15] E Saarisalo, E Skyttä, A Haikara, T Jalava and S Jaakkola. Screening and selection of lactic acid bacteria strains suitable for ensiling grass. J. Appl. Microbiol. 2007; 102, 327-36.

[16] H Alhaag, X Yuan, A Mala, J Bai and T Shao. Fermentation characteristics of lactobacillus Plantarum and Pediococcus species isolated from sweet sorghum silage and their application as silage inoculants. Appl. Sci. 2019; 9, 1247.

[17] M Kizilsimsek, RJ Schmidt, LJR Kung. Effects of a mixture of lactic acid bacteria applied as a freeze-dried or fresh culture on the fermentation of alfalfa silage. J. Dairy Sci. 2007; 90, 5698-705.

[18] EC Lara, FC Bassoa, FBD Assis, FA Souza, TT Berchielli and RA Reis. Changes in the nutritive value and aerobic stability of corn silages inoculated with Bacillus subtilis alone or combined with Lactobacillus plantarum. Anim. Prod. Sci. 2015; 56, 1867-74.

[19] S Mohd-Setapar, N Abd-Talib and R Aziz. Review on crucial parameters of silage quality. APCBEE Procedia 2012; 3, 99-103.

[20] E Salvucci, JG LeBlanc and G Pérez. Technological properties of lactic acid bacteria isolated from raw cereal material. LWT Food Sci. Technol. 2016; 70, 185-91.

[21] MO Dalheim, NB Arnfinnsdottir, G Widmalm and BE Christensen. The size and shape of three water-soluble, non-ionic polysaccharides produced by lactic acid bacteria: A comparative study. Carbohydr. Polym. 2016; 142, 91-7. 
[22] FE Contreras-Govea, RE Muck, GA Broderick and PJ Weimer. Lactobacillus plantarum effects on silage fermentation and in vitro microbial yield. Anim. Feed Sci. Technol. 2013; 179, 61-8.

[23] VL Nsereko, BK Smiley, WM Rutherford, A Spielbauer, KJ Forrester and GH Hettinger. Influence of inoculating forage with lactic acid bacterial strains that produce ferulate esterase on ensilage and ruminal degradation of fiber. Anim. Feed Sci. Technol. 2008; 145, 122-35.

[24] ZG Weinberg, RE Muck and PJ Weimer. The survival of silage inoculant lactic acid bacteria in rumen fluid. J. Appl. Microbiol. 2003; 94, 1066-71.

[25] ZG Weinberg, Y Chen and M Gamburg. The passage of lactic acid bacteria from silage into rumen fluid, in vitro studies. J. Dairy Sci. 2004; 87, 3386-97.

[26] RE Muck, I Filya and FE Contreras-Govea. Inoculant effects on alfalfa silage: In vitro gas and volatile fatty acid production. J. Dairy Sci. 2007; 90, 5115-25.

[27] G Pahlow, RE Muck, F Driehuis, S Elferink and SF Spoelstra. Microbiology of ensiling. Agronomy. 2003; 42, 31-94.

[28] LE Phillip and V Fellner. Effects of bacterial inoculation of high-moisture ear corn on its aerobic stability, digestion, and utilization for growth by beef steers. J. Anim. Sci. 1992; 70, 3178-87.

[29] TA McAllister, LB Selinger, LR McMahon, HD Bae, TJ Lysyk, SJ Oosting and KJ Cheng. Intake, digestibility and aerobic stability of barley silage inoculated with mixtures of Lactobaciollus plantarum and Enterococcus faecium. Can. J. Anim. Sci. 1995; 75, 425-32.

[30] RE Muck. Effects of corn silage inoculants on aerobic stability. Trans ASAE. 2004; 47, 1011-6.

[31] H Zahiroddini, J Baah, W Absalom and TT McAlister. Effect of an inoculant and hydrolytic enzymes on fermentation and nutritive value of whole crop barley silage. Anim. Feed Sci. Technol. 2004; 117, 317-30.

[32] Association of Official Analytical Chemists (AOAC). The association of official analytical chemists. $17^{\text {th }}$ ed. Official Analytical Chemists, Arlington, Virginia, 2005.

[33] PJ Van Soest, JB Robertson and BA Lewis. Methods for dietary fiber, neutral detergent fiber, and nonstarch polysaccharides in relation to animal nutrition. J. Dairy Sci. 1991; 74, 3583-97.

[34] S Bureenok, W Suksombat and Y Kawamoto. Effects of the fermented juice of epiphytic lactic acid bacteria (FJLB) and molasses on digestibility and rumen fermentation characteristics of ruzigrass (Brachiaria ruziziensis) silages. Livestock Sci. 2011; 138, 266-71.

[35] LJR Kung, RD Shaver, RJ Grant and RJ Schmidt. Silage review: Interpretation of chemical, microbial, and organoleptic components of silages. J. Dairy Sci. 2018; 101, 4020-33.

[36] Department of Livestock Development. Standard guide of silage. The agricultural Co-operative fereration of Thailand, LTD., Thailand, 2004, p. 23.

[37] $\mathrm{KH}$ Menke and H Steingass. Estimation of the energetic feed value obtained from chemical analysis and gas production using rumen fluid. Anim. Res. Dev. 1988; 28, 7-55.

[38] ER Ørskov and I McDonald. The estimation of protein degradability in the rumen from incubation measurements weighted according to rate of passage. J. Agri. Sci. 1979; 92, 499-503.

[39] I McDonald. A revised model for the estimation of protein degradability in the rumen. J. Agric. Sci. $1981 ; 96,251-2$.

[40] S Mathew, S Sagathewan, J Thomas and G Mathen. An HPLC method for estimation of volatile fatty acids of ruminal fluid. Indian J. Anim. Sci. 1997; 67, 805-7.

[41] M Woolford and G Pathow. The silage Fermentation. Microbiology of Fermented Foods, Blackie Academic and Professional, London, UK. 1997, p. 73-102.

[42] RY Leibensperger and RE Pitt. Modelling the effects of formic acid and molasses on ensilage. $J$. Dairy Sci. 1988; 71, 1220-31.

[43] MD Flythe and JB Russel. The effect of $\mathrm{pH}$ and a bacteriocin (bovicin HC5) on Clostridium sporogenes MD1, a bacterium that has the ability to degrade amino acids in ensiled plant materials. FEMS Microbiol. Ecol. 2004; 47, 215-22.

[44] G Borreani, E Tabacco, RJ Schmidt, BJ Holmes and RE Muck. Silage review: Factors affecting dry matter and quality losses in silages. J. Dairy Sci. 2018; 101, 3952-79.

[45] E Tabacco, F Righi, A Quarantelli and G Borreani. Dry matter and nutritional losses during aerobic deterioration of corn and sorghum silages as influenced by different lactic acid bacteria inocula. $J$. Dairy Sci. 2011; 94, 1409-19.

[46] LJR Kung, AC Sheperd, AM Smagala, KM Endres, CA Bessett, NK Ranjit and JL Glancey. The effect of preservatives based on propionic acid on the fermentation and aerobic stability of corn silage and a total mixed ration. J. Dairy Sci. 1998; 81, 1322-30. 
[47] DH Kleinschmit and LJR Kung. A meta-analysis of the effects of Lactobacillus buchneri on the fermentation and aerobic stability of corn and grass and small-grain silages. J. Dairy Sci. 2006; 89, 4005-13.

[48] MR Bedford and GG Partridge. Enzymes in Farm Animal Nutrition. CABI Publishing, New York. 2001, p. 406. 